\title{
Pedagogic Thinking that Grounds E-Learning for Secondary School Science Students in New Zealand
}

\author{
ROBERT SHAW \\ The Open Polytechnic of New Zealand \& \\ the Carter Observatory, New Zealand
}

\begin{abstract}
Course designers adopted a language-learners approach to the online teaching of New Zealand secondary school students in the subject of astronomy. This was possible because the curriculum for astronomy that was in 2004 established as a part of New Zealand's national curriculum was specifically designed to engage underachieving students in science and technology. A criterionreferenced assessment regime was established and an Internet platform was built specifically to facilitate this form of assessment. This platform contrasts with the norm-referenced assessment programmes that are most frequently used with online instruction. In this situation - where the essential task is to reward students for learning basic vocabulary and to motivate them to further study - the theory of psychologist William James assisted the teachers to develop their online pedagogy. The article concludes with a comparison of the advantages and disadvantages of using the Internet to deliver science courses to secondary school students.
\end{abstract}

\section{Introduction}

Educators are challenged to base innovations on adequate theory. This is pressing in distance education:

The major theoretical challenge facing Distance Education, as the technology available to it advances at a remarkable rate, resides in developing didactic constructs which are appropriate. (Buachalla, 1989, p. 76)

This article describes ideas that were useful when pedagogical decisions were taken as developers built an online facility which teaches secondary school science. These ideas did not come from recent learning theory, but rather from psychological theory that was published in 1890. The pedagogy required in secondary education contrasts with that in tertiary education. (Most of the discussion to date centres on tertiary education, for example, in science education [Ross \& Scanlon, 1995].)

The pedagogy depended on the characteristics of the student population and nature of edelivery. The student population was a group identified by the New Zealand Government as being a national priority cohort, in need of academic success, and unlikely to take a serious interest in science or technology.

The National Observatory of New Zealand, the Carter Observatory, constructed a website (http:/ / www.carterobservatory.net) that presents three astronomy unit standards which the New Zealand Qualifications Authority had in 2004 established (New Zealand Qualifications Authority, 2007a). The website was designed, funded, and built entirely by the Observatory. The teaching facility was first discussed publicly at a teachers' union conference in 2004 (Shaw, 2004a).

The theory of psychology that informs the pedagogy is the focus of the present article. However, it was not the only theory found useful. In marked contrast to the theory of psychology, there were also ontological considerations that were found relevant (Shaw, 2004b; R. Shaw, 2005). The look, feel, and functioning of the website was deliberately based on a pedagogy influenced by 
James and Heidegger. This analysis opposes the determining effect of technology that now causes disquiet in schooling, as much as it is engenders apprehension in higher education (Clegg et al, 2003).

The website draws students from secondary schools throughout New Zealand and they interact directly with specialist teachers who are online $24 / 7$. After three years of operation, the system in May 2007 was teaching and assessing 749 secondary school students and 1075 primary school students (they are not considered in the present article). The facility could easily manage up to about 20,000 students, the main limitation being the number of teachers available. It would be possible to employ teachers who are overseas, but to date all the teachers have lived in Wellington.

This article argues that the pedagogy developed - when used to address the specific situation described - rivals classroom teaching. A comparison of classroom and online teaching is provided to highlight the advantages and disadvantages of each.

\section{National Science Education Policy Drives Pedagogy}

Science education is weak in New Zealand. There are not enough qualified teachers and the work is not well paid. The challenges of science education have been summarised by the New Zealand Council for Educational Research (Hipkins et al, 2002). For over 20 years the country has sought ways to increase the number of graduates in science and technology. A possible decline in student numbers has been reported, although it is emphasised that the situation is complex and may be measured in different ways (Hipkins \& Bolstad, 2005). A report commissioned by a committee chaired by the Prime Minister and comprising both Cabinet Ministers and business leaders counselled:
In order to grow as a knowledge economy, our young people need the grounding to pursue higher education in the physical and life sciences. Our early maths and science education may need strengthening relative to countries such as Singapore and Australia. In addition, the marked decline in participation rates through high school suggests that there is a pressing need to inspire young people to continue with maths and science subjects. World-class performance in maths and science has to be achieved across a much broader spectrum of the population. Lifting the quality of maths and science teaching at primary and lower secondary levels may be required in order to inspire children and teenagers that these are core educational requirements if they want a rewarding career in the knowledge economy. (L.E.K. Consulting, 2001, p. 99)

Work is being done to advance these issues. One of the Government's five critical social issues as priorities for inter-agency action over the next three to five years is improved educational achievement among low socio-economic groups', and this was brought into science policy (Ministry of Research, Science and Technology, 2006, p. 12). Attempts have been made to associate science with business (Bolstad, 2004).

Large urban secondary schools typically have specialist physics teachers; however, rural schools are likely to have only one or two science teachers, neither of whom are specialist physics teachers. Frequently, the science teachers' degree qualifications do not take physics to a high level and apparently no science teacher holds a higher qualification in astronomy.

Yet it is not the challenge of science education that primarily occupies the New Zealand Government. There is a greater challenge in the dramatically growing student population that struggles with basic literacy and social outcomes (my interpretation of New Zealand Ministry of Education, 2005; see p. 41 for example where the monitoring of social outcomes is given as equally important as the monitoring of academic outcomes). Demographics are the foundation of this challenge. The country must increasingly channel resources into literacy programmes and basic education that, although now delivered in secondary schools, have traditionally been the province of primary schools (my interpretation of New Zealand Literacy Taskforce, 1999).

From this description of national educational need it is apparent that a course delivered nationally by online, specialist, science teachers is attractive - particularly if that course offers the opportunity of academic success to lower achieving students. 


\section{Needs of the Students a Critical Foundation for Pedagogy}

All teaching begins with the teacher's knowledge and assumptions concerning the students. All too frequently authors write about e-learning in a generic way. They write as if web based instructional technique is universally applicable, which it most clearly is not, any more than are the techniques of classroom teaching. As has been advised, web-based learning will only be a success if those involved:

acknowledge and take into account differences in student/ user backgrounds in every phase of

the design and delivery of online materials and support. (Brennan et al, 2001, p. 8)

One mantra of curriculum theorists is that we build curricula on philosophical, psychological, and sociological theory. With regard to the astronomy website, psychological and ontological theories are most prominent in the discussions of those involved in its design. The definition of the task and the methods of teaching express beliefs about the student population and student needs.

The students likely to enter the astronomy online courses are of two kinds. First, many students are excited about astronomy. They watch the achievements reported on television, know the websites of the many scientific organisations such as NASA, take an interest in the night sky, and visit local observatories. They sometimes say that the absence of astronomy in their school curriculum frustrates them. These students are competent in using the Internet and sometimes are oriented towards science and technology to the exclusion of other things. Academic competition may motive them. They gain recognition and rewards from their academic progress.

The second group - by far the largest - is the most important group with regard to national science policy as set out above. These students are often not achieving academically. They have minimal interest in science. They struggle to find a footing in a world of movement and pressures that they do not understand. They orient towards their friends, and teachers expect them to leave school at a younger age and not enter tertiary education. Their language skills are possibly weak. They do not focus well on schoolwork. They sometimes avoid school. Their schooling, in some cases, fragments because of family relocations. Money is frequently a household problem. Substance abuse may be present in the lives of their families or associates, and their families may be familiar with the criminal justice system. In their world, schoolwork struggles to become a priority. These students are those who are relevant to the government policy described earlier.

The teaching facility, deliberately, directs itself at the needs of the second group. Accordingly, it does not aim at gifted students or those students who are highly motivated by science and technology (although many of these students enjoy the online courses). Nor is it for those who are highly competent in their use of the Internet. Nor it is for students from wealthy families that provide their children with high-speed Internet connections. For the National Observatory of New Zealand this was a significant alteration in audience and purpose. It came from the strategic planning of the Board of the Observatory in 2000-01. It moved the Observatory towards being a significant instrument of national education policy.

\section{Assessment System Foundational to Pedagogy}

The underachieving student population (described as the second group above) is more likely to work for recognition within the formal qualifications system than they are to work because of their interest in science. It was the characteristics of the students that drove the developers' interest in the assessment regime. The assessment regime itself can motivate students.

National norm-referenced assessments for students aged 15, 16 and 17 years dominated New Zealand secondary schooling until 1986. They were the examinations of School Certificate, University Entrance/Sixth Form Certificate, and Scholarship/Bursary (New Zealand Qualifications Authority, 2007b, c ; New Zealand Qualifications Authority, 2007c). In a dramatic move in the 1980 s, the Government replaced the functioning system with a criterion-based system that reduced competition between students and brought the opportunity to diversify to the curriculum. The criteria are known as standards. Even to this day, teachers and parents can misunderstand the new system. Employers, who were one of the driving forces behind the change, have found it produces better information on job applicants. (The changes were monitored by the New Zealand Council for Educational Research, [Hipkins et al, 2004].) 
The opportunities offered by criterion-based assessment were pre-eminent in the design of the teaching and assessment system. Each student has to prove his or her ability against specific criteria. In the assessment process there is no need to refer to the results achieved by other students. To this day, many teachers in secondary schools use tests and examinations that are norm-referenced. The students achieve a percentage result and by this means compete with each other. The website precludes such comparisons.

The website teaches and assesses each part of the curriculum in turn. The student must achieve total success with the questions that relate to each part. If they do not the computer program cycles them around and they do not get beyond the topic.

When teachers come to assess a student's response to questions (which they do totally online), they see the student's details, the question, the student's written answer, and the marking schedule for that question. The teacher then ticks a box to say the student has achieved and writes a response to the student. The teacher will address errors and appropriately reinforce the student's response. The teaching, in this way, is far more specific than what teachers can achieve in a normal classroom. Classroom teachers simply do not have the time to respond to every statement that every student makes. The website includes facilities to make the work of the online teacher efficient. For example, there are programmed standard responses. Some teachers like to use their own external database with an automatic paste facility to speed up the provision of personal responses. The responses to the student are not just about astronomy. Frequently, innocuous comments are made about the weather in Wellington (the teacher's location), current sporting events, and pets. This is to help build the personal relationship with the teacher/website. However, care is taken not to distract the student from their work.

Accordingly, the approach to assessment drives the approach to the presentation of teaching materials and the relationship with the teacher. One issue for the developers of the system is the quantity of material presented before there is a question. Developers call this 'block size'. Generally, block size is one screen length (in the jargon of developers a 'screen-full'). The section on teaching below develops this theory further.

A further implication of this approach to assessment relates to the time available to complete a course. This is set at an arbitrary one year. Accordingly, students can work when they like and at their own pace. They can begin in their school holidays or at weekends. They can work at home, in libraries, or at school. They can work wherever they can access the Internet. They can follow their own 'biological clock'.

This work pattern for students is different from the situation built around classrooms. However, the radical difference here is to do with the duration of school courses. In classroom teaching the students have to conform to the assessment pattern that applies to the group. There are fixed times for summative assessment. The online criterion-referenced student faces continual, progressive assessment that is totally independent of any other student or teacher requirements. This facilitates pedagogical individualisation.

\section{Psychology as the Foundation of Pedagogy}

Forestructures are critical in all educational development projects. (The terminology used here is derived from Heidegger's work on questioning.) In terms of practice, forestructures of thought revolve around:

1. The definition of the task as conveyed by the governance body. In this case there was a vision statement and other defined parameters.

2. The selection of the project team, and in particular its theoretical orientation.

3. The selection of the theorists that will inform decision-making.

4. The attitude to be taken towards the theory.

The selection of project teams is discussed in Shaw (2005). In this project, funding precluded the formal employment of consultants.

What thinking was it that aligned this project to James's theoretical text published in 1890 ? Five factors may be discerned:

1. The strong orientation towards the needs of individual students indicated that the project should consider a psychologist of the individual, as opposed to those who are concerned about 
(say) group dynamics or classroom pedagogics, or wider social goals such as democracy or citizenship.

2. A leading characteristic of personal computing - particularly when supported by the Internet is that decision making is highly individualistic and personal. Aligned with this is the frequency with which a person on the Internet makes decisions. Every few seconds a decision may be made. A psychological theory that emphasises decision making is attractive.

3. Students are very much alone with their machines. There is a freedom in working on the Internet that comes from the absence of peer pressure. It is an escape from the student's world as described above. This inclined the project towards both Heidegger and James.

4. What the students had to learn, the content as prescribed by the unit standard, was highly specific. One feature of a criterion-based assessment system is that it defines a standard to be achieved with regard to each individual, discrete content item. James is concerned about the learning of specific things. The contrast might be with those who are concerned about philosophical issues regarding creativity and inspiration in the learning of science (see, for example, the edited collection of Dutton \& Krausz, 1981).

5. James develops his principles of learning from a discussion of space and space perception. He also considers 'things' specifically. Consequently, Descartes' dualism of mind and body is prominent in James's work, and contributes to a mechanistic theory of learning. This mechanistic, technological account of human beings correlates well with the aseptic, sanitised, quality of online teaching. The teacher does not face students in a direct and personal way. The developers have the ability to tightly control the learning environment - if by 'learning environment' is meant what is delivered by the computer alone.

James's principles of learning that are particularly relevant are: habit, instinct, attention, associations, and memory. Habit produces ease of action. It is the nature of human beings that they are 'bundles of habits' (James, 1890, pp. 68-69). As he argues by analogy:

Everyone knows how a garment, after having been worn a certain time, clings to the shape of the body better than when it was new; there is a change in the tissue, and this change sis IS?? a new habit of cohesion. (James, 1890, p. 69)

His discussion of habit formation describes the importance of consistent, repeated action. Without any knowledge of microtubules and neural networks, he speculates about how changes must be occurring in the brain as habits are instilled. The importance of attention in habit formation is also discussed (p. 74) along with the coordination of mind, hand, and eye (p. 75). The student website seeks by clarity of direction and repetition of student action to rapidly build habits. When the student begins a new session at the computer, we seek to have their actions repeat those of earlier sessions. Accordingly, we do not distract the student with messages that do not relate directly to their goal. We seek to have them repeat the same sequence of mouse clicks, and confront the same visual pattern as previously. Our website must be 'old reliable'. This carries over to the way that learning materials are presented and the approach to answering questions. As James says of habit formation:

Seize the very first possible opportunity to action on every resolution you make, and on every emotional prompting you may experience in the direction of the habits you inspire to gain.

(James, 1890, p. 81)

The website seeks to facilitate the opportunities and the emotional prompting. Students who are new to the website already have an instinct about it because of their previous experience of computing. Instinct is the 'faculty of acting in such a way as to produce certain ends without foresight of the ends without previous education in the performance' (James, 1890, p. 700). The teaching facility seeks to capitalise on the students' past experience of websites. Accordingly, it seeks to be a simple example of what is common. It does not seek to be ultra-modern or exciting. Many who are involved in the provision of distance education fail to understand this point and build ever more exciting and innovative gimmicks, allegedly to motivate students. It is a serious mistake if student learning is the ultimate goal. This is particularly so for serious students, who can resent misdirection.

If one concept of learning is pivotal in the teaching facility it is attention. James says everyone knows what attention is: 
It is the taking possession by the mind, in clear and vivid form, of one out of what seem several simultaneous possible objects or trains of thought. (James, 1890, p. 261)

Classroom teachers understand attention very well. 'Pay attention', they say to classes. Attention is aligned to the more mental idea of being able to concentrate. The description of the students given above justifies the need to attend to attention. The inability of the student to consistently focus exactly on the matter to be learnt is a probable barrier to learning. Looked at from the perspective of success, Nuthall asked experienced teachers how they knew learning was taking place:

Almost every teacher knew their teaching was going well from signs of students' engagement. It was the look in the students' eyes, the questions they asked, the fact that they didn't stop talking about the topic or problem when they left the classroom. In short, by the feel and sounds of interest and focussed busyness. (Nuthall, 2005, pp. 92-93)

The online equivalent is more objective. What counts is the length of time the student works on the website and the number of questions they answer in a session. There is an important caveat: this assumes the website engages them in real learning and it assumes they have a serious attitude as they answer the questions. 'Being busy is not a cause of learning unless you know exactly what information or knowledge the student is getting by being busy' (Nuthall, 2005, p. 93). Those who suggest that student chat facilities be added to the website do not understand the imperatives. A chat facility would legitimise the avoidance of engagement with the content of the course. It would not assist the student to attend. Given the student population described above, this is serious. Likewise, the students' engagement with the online teacher must always bring the student back to the content with a minimum of delays. The teacher must maintain the attention of the student on the course content. The humanising interactions described above (for example, mentioning the weather) have to be kept within strict bounds and by being regular and formal they contribute to the reliability of the site, which relates to both habit formation and attention.

Another aspect of attention is the layout of materials on the screen. The intention is that all students are taught on the screen. The students described above too frequently arrive at their classrooms without their books or even a pen. The idea of having a required book to accompany the online course is often suggested, but it could very easily be counterproductive. It is not desirable that work sessions begin with a hunt for equipment.

Many trials were conducted to judge the operative length of material to be presented. One rule that emerged was that the material should be in natural blocks. This means that topics should be presented as a meaningful whole. But equally important is that there should not be more than three short paragraphs before the student is required to make a response with their mouse.

To manage the teacher workload but to ensure the optimum level of engagement with the student, short machine-marked multiple-choice items are sometimes inserted between paragraphs. Between topics, simple multiple-choice questions are designed to maintain the students' attention but without bringing the student away from the content. For example, 'You are now half way though your course. You have 2 of the 4 credits this course will produce for you. Well done! How are you finding it: easy, okay, hard?' The machine returns a suitable response to the student instantly and in the teacher's name.

The online student - as an individual - drives the teacher. To obtain a response from the teacher the student must make a submission. We know that student achievement is greatly enhanced when teachers respond positively (Hughes, 1973). Consequently, it is quite possible that the quality and level of direct teacher response to students is greater in the online situation described than in most classroom situations. It may be reasoned that learning is greater having regard to the well-accepted findings of Hughes and others.

Lapses of attention are important considerations. According to James, lapses are common:

Most people probably fall several times a day into a fit of something like this: The eyes are fixed on vacancy, the sounds of the world melt into confused unity, the attention is dispersed so that the whole body is felt, as it were, at once, and the foreground of consciousness is filled, if by anything, by a sort of solemn sense of surrender to the empty passing of time. In the dim background of our mind we know meanwhile what we ought to be doing. (James, 1890, p. 261)

Something like this occurs as students study. Classroom teachers observe the phenomenon students 'daydream' they say. For the website the essential point about student 'daydreaming' is 
that the notion of what the student 'ought to be doing' is maintained in the student's mind, and that there is no competition for their attention. A pause may well be necessary for the mental wellbeing of the student. Accordingly, it may need to happen; however, the return to attending to content must be facilitated. It is in the ability of distance education to manage these events that they could show superiority to classroom teaching.

Another aspect of attention relates to the design of the website. Clark \& Mayer (2003, pp. 111-128) set out in detail, and with humour, the tension between good pedagogy and the requirements of customers who seek to have teaching websites constructed. They appeal to a 'coherence principle' (defined as: 'People learn more deeply from multimedia lessons when distracting stories, graphics, and sounds are eliminated', p. 310). For the students described above, objects on the screen need to look sparse. The flow of text and graphics must be strictly horizontal. Only three sizes of graphic are used. Essentially, the screen is to look like a piece of paper. For that reason the teaching space is white. As has been said, 'seductive details' do not assist with serious learning (Clark \& Mayer, 2003, p. 115). The experience with the student population described indicates that they perceive the website to be about 'real work'. They work there to advance themselves, and not to be entertained. According to the evaluations collected from students, they are perfectly satisfied with a Spartan website although frequently adults who have not been students seek to have our site enhanced with 'modern' features.

A further aspect of attention relates to the provision of an online teacher. It might be thought that the teacher is present to teach astronomy. That is not so. The teacher is present to assess the student and to motivate the student. The website is designed to teach without human intervention. The most motivating factor within the teaching facility is the teacher's response. This is designed not to engage the student for more than a moment, but to bring the student on to attend to the next topic. The personalisation principle that some advocate for instructional websites is helpful (Clark \& Mayer, 2003, p. 184). But when this translates into the provision of a 'virtual coach' it is woefully inadequate for secondary school students.

There is another useful comparison between classroom and online teaching that draws upon James's theory of associations. The limitation of classroom teaching is that it is about groups. Nuthall likens classroom teaching to the management of an orchestra. All is going well when the orchestra makes a certain sound, through recurring patterns of whole-group activities. However, this indicates nothing about the learning of individuals:

I now began to understand the function of the standard patterns or routines of teaching and why they had such control over teachers' behaviour. In order to manage a class of 25 to 35 students, all of whom have different knowledge, skills, interests, and motivations, teachers have to focus on the performance of the class as a whole. It is impossible to focus on the individual learning of any one student for more than very brief periods. (Nuthall, 2005, pp. 85-86)

The problem of how thoughts come to be connected, of how associations are made, is critical for learning theory. James begins by emphasising that much depends on the mechanical conditions under which things are brought together, and develops a 'law of contiguity'. Before association is possible, there must be discrimination. The items to be associated must be conceived as different things.

There are, then, mechanical conditions on which thought depends, and which, to say the least, determine the order in which is presented the content or material for her comparisons, selections, and decisions. (James, 1890, p. 361)

And he continued:

objects once experienced together tend to become associated in the imagination, so that when any one of them is thought of, the others are likely to be thought of also, in the same order of sequence or coexistence as before. (James, 1890, p. 367)

This is his law of mental association by contiguity. What is mentally associated with classrooms has been summarised by empirical researchers:

We began to realise that students live in a personal and social world of their own in the classroom. They whisper to each other and pass notes. They spread rumours about girlfriends and boyfriends, they organise their after-school social life, continue arguments started in the 
playground. They care more about how their peers evaluate their behaviour than they care about the teacher's judgement. (Nuthall, 2005, p. 85)

Through all of this the students learn content. However, there are questions to be asked about the efficiency of such learning. We must be concerned that it is the student population identified above - those who are already underachieving - which is most disadvantaged by distractions in classrooms.

James's account of memory provides a further useful insight that is helpful to developers. He divides the methods of memory into mechanical, ingenious, and judicious:

The mechanical methods consist in the intensification, prolongation, and repetition of the

impression to be remembered. (James, 1890, p. 437)

The impression in the case of a teaching website is generally on a screen, but audio reinforcement is helpful. The intense challenge is to present ideas in simple language. A teaching website for secondary school students needs to take a 'language learners' approach to teaching. It is the facility of repetition, however, that attracts debate. The infinite patience of computers may be used to good advantage, although judgement is required. A course is of a particular length, described by the number of 'screen-fulls' and the number of questions. Throughout the website and in all the courses, a deliberate effort is made to use the same words to describe the same things. In the discipline of astronomy this can entail a choice. Once the word for an object or concept is selected, the task becomes describing that word or that concept. James reports experiments to reveal how long it takes to learn certain things. Such experiments need to be conducted for web-based learning systems. The length of time that it takes students to complete the National Observatory's courses varies from about one week to about 10 months. The average is about four months. At present there is no data available on what this means.

\section{A Comparison of Internet and Classroom Pedagogy}

This article argues that the online teaching of science in the model developed by the National Observatory of New Zealand produces for students an experience that is significantly different from the experience of learning in classrooms.

Table I compares the regular students' experience of quintessential classroom teaching with their experience of the National Observatory's website. The table is indicative and there is an opportunity for debate and empirical research in this area.

\begin{tabular}{|c|c|}
\hline Online experience & Classroom experience \\
\hline Work sessions can be of any duration. & Work sessions are of 45 minutes. \\
\hline Work sessions can begin at any time of the night or day. & $\begin{array}{l}\text { Work sessions are structured into specific times during } \\
\text { the day. }\end{array}$ \\
\hline $\begin{array}{l}\text { There is little opportunity to move outside of the set } \\
\text { content. }\end{array}$ & There is scope to build upon student interests. \\
\hline $\begin{array}{l}\text { The motivational techniques are set as a part of the } \\
\text { delivery system. }\end{array}$ & Teachers can vary motivational techniques. \\
\hline $\begin{array}{l}\text { Summative assessment occurs as an integral part of } \\
\text { learning (page-by-page). }\end{array}$ & $\begin{array}{l}\text { Summative assessment is an 'event', frequently at the } \\
\text { end of a week or a term. }\end{array}$ \\
\hline $\begin{array}{l}\text { A second-order form of personal relationship may develop } \\
\text { with the teacher. }\end{array}$ & $\begin{array}{l}\text { Genuine personal relationships are facilitated by direct } \\
\text { personal contact. }\end{array}$ \\
\hline $\begin{array}{l}\text { The teacher responds to the student within a few minutes } \\
\text { in every case. There is only one channel of } \\
\text { communication. }\end{array}$ & $\begin{array}{l}\text { Teachers sometimes do not respond to individual } \\
\text { students and the time taken to respond depends on the } \\
\text { nature of the student's submission (for example, an } \\
\text { oral question or an examination script). }\end{array}$ \\
\hline $\begin{array}{l}\text { Assessment occurs as each concept is studied by the } \\
\text { individual. }\end{array}$ & $\begin{array}{l}\text { Assessment occurs when the timetable allows, with the } \\
\text { curriculum accumulated by the group. }\end{array}$ \\
\hline $\begin{array}{l}\text { The teacher sees every statement the student makes and } \\
\text { can comment on it. }\end{array}$ & $\begin{array}{l}\text { Teachers often collect work from students and view it } \\
\text { after the class is complete. }\end{array}$ \\
\hline $\begin{array}{l}\text { Progress is reported question-by-question and a graph } \\
\text { shows the student exactly how far they are through the }\end{array}$ & $\begin{array}{l}\text { Students can become unaware of their individual } \\
\text { achievement when taught in a group. }\end{array}$ \\
\hline
\end{tabular}


Course completion produces an immediate congratulatory statement, and an invitation to enter the next course.
There are usually delays before the results of courses are known.

Table I. The students' experience: the table compares online and classroom education as shown in the examples of the National Observatory's facility and New Zealand science teaching.

Considered from the perspective of national education policy, the online system compares to regular schools as follows (Table II).

\begin{tabular}{|c|c|}
\hline Online delivery & Classroom delivery \\
\hline $\begin{array}{l}\text { Closer control over the quality of teaching and } \\
\text { assessment because all student-teacher interactions are } \\
\text { recorded and available for audit. }\end{array}$ & $\begin{array}{l}\text { What happens in classrooms is difficult to monitor and } \\
\text { audit. }\end{array}$ \\
\hline Every student is taught by a specialist teacher. & $\begin{array}{l}\text { Science teachers may be weak in specific disciplines and } \\
\text { there can be teacher shortages in some schools. }\end{array}$ \\
\hline $\begin{array}{l}\text { The specialist workforce that develops around the } \\
\text { management and development of the website forms a } \\
\text { focus for teacher education. }\end{array}$ & $\begin{array}{l}\text { Teacher education depends largely on the provisions in } \\
\text { universities and teacher unions. }\end{array}$ \\
\hline $\begin{array}{l}\text { Efficiency in the use of the teachers' time. Teachers only } \\
\text { teach and assess. }\end{array}$ & $\begin{array}{l}\text { Teachers are responsible for student management and } \\
\text { many other non-teaching tasks. }\end{array}$ \\
\hline $\begin{array}{l}\text { The curriculum is delivered to the student in a uniform } \\
\text { way with an assurance that each topic receives its correct } \\
\text { curriculum weighting. }\end{array}$ & $\begin{array}{l}\text { Curriculum drift can occur as teachers emphasise the } \\
\text { topics that interest them and stray from the course } \\
\text { requirements. This can motivate students. }\end{array}$ \\
\hline $\begin{array}{l}\text { The presence of the highly specific markers' schedule } \\
\text { facilitates accurate assessment question-by-question. } \\
\text { It is possible for lead teachers to insert messages into the } \\
\text { marking schedule to improve assessor performance. }\end{array}$ & $\begin{array}{l}\text { Marker drift can occur when teachers mark tests for } \\
\text { whole classes. Internal moderation may prevent this. } \\
\text { Heads of departments may influence the assessment } \\
\text { practices of teachers. }\end{array}$ \\
\hline $\begin{array}{l}\text { Information for the moderation of assessments is readily } \\
\text { available. A moderation report can be printed for any } \\
\text { selected student by clicking a button. }\end{array}$ & $\begin{array}{l}\text { Moderation requirements generally require the keeping } \\
\text { of student tests (usually in paper form), and the } \\
\text { management of moderation is a burden for teachers. }\end{array}$ \\
\hline $\begin{array}{l}\text { Reports that make comparisons of students, particular } \\
\text { questions, particular makers, or schools, are readily } \\
\text { produced. }\end{array}$ & $\begin{array}{l}\text { The making of comparisons generally requires a specific } \\
\text { research project with a data collection phase. }\end{array}$ \\
\hline $\begin{array}{l}\text { Student achievement accumulates as the teachers assess. } \\
\text { There is no teacher administration. }\end{array}$ & $\begin{array}{l}\text { Teachers have to record student achievement. Many use } \\
\text { 'mark-books'. It is necessary to accumulate and } \\
\text { transcribe to a central system the marks given by } \\
\text { teachers. }\end{array}$ \\
\hline The final result is immediately reported to the student. & $\begin{array}{l}\text { There is often a delay in reporting the final result to an } \\
\text { individual when students are assessed in groups. }\end{array}$ \\
\hline Courses are available to all students nationally. & $\begin{array}{l}\text { It is necessary to have a number of students interested in } \\
\text { a particular course before a school can offer that course. }\end{array}$ \\
\hline $\begin{array}{l}\text { It is relatively easy to measure the cost of teaching each } \\
\text { student. }\end{array}$ & $\begin{array}{l}\text { The cost of science teaching and assessment is often } \\
\text { dispersed within the various budgets of the school. }\end{array}$ \\
\hline $\begin{array}{l}\text { The cost of course delivery is significantly less than that } \\
\text { in a normal school. The benefits delivered for these costs } \\
\text { are restricted to the delivery of the course content and } \\
\text { assessment. }\end{array}$ & $\begin{array}{l}\text { The cost of course delivery is often unknown because } \\
\text { accounts do not distinguish teaching duties from school } \\
\text { overheads and the teachers' pastoral duties. The benefits } \\
\text { of schooling for students are greater than those of course } \\
\text { delivery. }\end{array}$ \\
\hline $\begin{array}{l}\text { Teachers may work from their own homes according to } \\
\text { a roster. Students usually work from schools or their own } \\
\text { homes. }\end{array}$ & $\begin{array}{l}\text { Teachers and students work the same hours at } \\
\text { centralised locations. They place pressure on road } \\
\text { transport and incur environmental costs. }\end{array}$ \\
\hline
\end{tabular}

Table II. The policy perspective: the table compares online and classroom education as shown in the examples of the National Observatory's facility and New Zealand science teaching. 


\section{Conclusion}

This article sets out how James's psychology was of use in the development of a teaching facility. This theorist's work was sympathetic to the needs of the student population and the opportunities of distance delivery. Of importance also was the approach to assessment that was recently made possible by reforms of the New Zealand secondary school qualifications system.

The use of James as a leading theorist in the development of the teaching facility does not mean that his ideas were simply 'adopted'. Instead, the theorist - through his writing - led the teachers' discussions. James contributed ideas that were congruent with the experiences of those involved in the development project.

The model of teaching and assessment described is for a very distinct group of students with specific needs and in particular circumstances. It is not to be thought of as sufficient for science education as a whole, which must involve practical work, personal interaction with others, and base itself upon the work of scientists. Instead, the online facility is one specific tool that may be used to strengthen an aspect of science education.

Many of the students taught by the National Observatory are Maori or Pasifika students. The pedagogy described has yet to consider them as a separate cohort. The extent of this challenge has been indicated:

Recent research on New Zealand students' achievement in science in 'mainstream' New Zealand classrooms carries clear challenges for science teachers. Three different research projects, both international and national, point to a systematic picture of underachievement in science for Maori and Pasifika students in New Zealand schools. (Waiti \& Hipkins, 2002, p. 1)

Schools report that their teachers enjoy interacting with the online teachers and hearing about course content from their students. The different mode of delivery stands in profound contrast to secondary school classroom delivery. There should now be an independent evaluation of the effects of the system on students. Finally, the economic gains of this method of teaching and assessment are alluring, particularly in situations were it is desirable to make specialist teachers available to a dispersed student population.

\section{Acknowledgements}

I would like to thank the members of the Board of the Carter Observatory, particularly Mike Doig, Phil Yock, Gary Wilmshurst and Richard Bentley. William Bryson produced over 200,000 lines of computer code for the website. The opinions in this article are mine alone.

\section{References}

Bolstad, R. (2004) Where Are Your Science Students Going (and How Can You Help Them Get There)? New Zealand Science Teacher, 106, 36-40.

Brennan, R., McFadden, M. \& Law, E. (2001) All That Glitters Is Not Gold: online delivery of education and training. Leabrook, South Australia: National Centre for Vocational Education Research.

Buachalla, S.O. (1989) Distance Education as an Element of Policy, European Journal of Education, 24(1), 73-78. http: / / dx.doi.org/10.2307/1503147

Clark, R.C. \& Mayer, R.E. (2003) E-Learning and the Science of Instruction: proven guidelines for consumers and designers of multimedia learning. San Francisco: Jossey-Bass/Pfeiffer.

Clegg, S., Hudson, A. \& Steel, J. (2003) The Emperor's New Clothes: globalisation and e-learning in higher education, British Journal of Sociology of Education, 24(1), 39-53. http: / / dx.doi.org/10.1080/01425690301914

Dutton, D. \& Krausz, M. (1981) The Concept of Creativity in Science and Art. The Hague: M. Nijhoff.

Hipkins, R. \& Bolstad, R. (2005) Staying in Science: students' participation in secondary education and on transition to tertiary studies. Wellington: New Zealand Council for Educational Research.

Hipkins, R., Bolstad, R., Baker, R., et al (2002) Curriculum, Learning and Effective Pedagogy: a literature review in science education. Report to the Ministry of Education. Wellington: Ministry of Education, Research Division. 
Hipkins, R., Vaughan, K., Beals, F. \& Ferral, H. (2004) Learning Curves: meeting student learning needs in an evolving qualifications regime: shared pathways and multiple tracks: a second report. Wellington: New Zealand Council for Educational Research.

Hughes, D.C. (1973) An Experimental Investigation of the Effects of Pupil Responding and Teacher Reacting on Pupil Achievement, American Educational Research Journal, 10(1), 21-37. http: / / dx.doi.org/10.2307/1162234

James, W. (1890) The Principles of Psychology, in R.M. Hutchins (Ed.) Great Books of the Western World (1987 edn, vol. 53). Chicago: University of Chicago.

L.E.K. Consulting (2001) New Zealand Talent Initiative: strategies for building a talented nation. Auckland: Steering Committee on Talent (Department of the Prime Minister and Cabinet).

Ministry of Research, Science and Technology (2006) Science for New Zealand: an overview of the RS\&T System, 2006. Wellington: Ministry of Research, Science \& Technology.

New Zealand Literacy Taskforce (1999) Report of the Literacy Taskforce: advice to the government on achieving its goal that: 'By 2005, every child turning nine will be able to read, write, and do maths for success'. Wellington: Ministry of Education.

New Zealand Ministry of Education (2005) Making a Bigger Difference for All Students: hangaia he huarahi hei whakarewa ake inga tauira katoa: schooling strategy 2005-2010. Wellington: Medium Term Strategy, Ministry of Education.

New Zealand Qualifications Authority (2007a) Domain - astronomy. http: / / www.nzqa.govt.nz / framework/ explore/ domain.do?frameworkId=278767 (accessed 14 May 2007).

New Zealand Qualifications Authority (2007b) Changes to Qualifications 1970-2001. http: / www.nzqa.govt.nz/qualifications/ssq/ changes.html (accessed 14 May 2007).

New Zealand Qualifications Authority (2007c) Previous Secondary Qualifications. http:/ / www.nzqa.govt.nz/ qualifications/ssq/prevqual.html\#schoolcertificate (accessed 14 May 2007).

Nuthall, G. (2005) The Cultural Myths and the Realities of Teaching and Learning, in B. Webber (Ed.) The Herbison Lecturers, 77-103. Wellington: NZCER Press.

Ross, S. \& Scanlon, E. (1995) Open Science: distance teaching and open learning of science subjects. London: Paul Chapman.

Shaw, R. (2004a) The Black Hole Theory of Teaching: the future of assessment and course delivery in New Zealand secondary schools. Paper presented at the New Zealand Post Primary Teachers' Association Conference, 'Charting the Future', Wellington, 18-20 April 2004.

Shaw, R. (2004b) Towards a Heideggerian Pedagogy. Paper presented at the 33rd Annual Conference of the Philosophy of Education Society of Australasia, Melbourne, 26-28 November 2004.

Shaw, R. (2005) Heidegger's Concept of Truth at Work in Western Schools: building an ontological model of truth and describing truth in the life of the student. Paper presented at the 34th Annual Conference of the Philosophy of Education Society of Australasia, Hong Kong, 24-27 November, 2005.

Shaw, R.K. (2005) Marshall - making Wittgenstein smile, Educational Philosophy and Theory, 37(3), 397-405. http:/ / dx.doi.org/10.1111/j.1469-5812.2005.00128.x

Waiti, P. \& Hipkins, R. (2002) Cultural Issues that Challenge Traditional Science Teaching, Third Annual New Zealand Science Education Symposium, Massey University, Wellington, Friday 22 and Saturday 23 November 2002. Wellington: New Zealand Council for Educational Research.

ROBERT SHAW is a senior lecturer in business analysis at the Open Polytechnic of New Zealand and a former secondary school physics teacher. He has been a member of the Board of the National Observatory of New Zealand, the Carter Observatory, and managed the development of their distance education platform. Mr Shaw is currently a PhD student at the University of Auckland and his project involves Heideggerian thinking in education. Correspondence: Robert Shaw, School of Business, The Open Polytechnic of New Zealand, Private Bag, Lower Hutt, New Zealand (robert@porirua.net). 